\title{
Functional and Typological Development Features of the Tatar-Language Press in the Republic of Tatarstan under Current Conditions
}

\author{
Lyailya Rashitovna Sabirova ${ }^{1}$, Rezeda Lokmanovna Zayni ${ }^{1}$, Aysilu Farsovna Galiyahmetova ${ }^{1}$ \& Rasima $^{2}$ \\ Mullayanovna Galieva ${ }^{1}$ \\ ${ }^{1}$ Kazan Federal University, Russia \\ Correspondence: Lyailya Rashitovna Sabirova, Kazan Federal University, Kremlyovskaya Street, 18, 420008, \\ Kazan, Russia.
}

Received: October 10, 2014 Accepted: October 21, 2014 Online Published: December 2, 2014

doi:10.5539/ass.v11n1p321 URL: http://dx.doi.org/10.5539/ass.v11n1p321

\begin{abstract}
The article analyzes the peculiarities of functional, typological and genre development of press in the Republic of Tatarstan in the current context. At present in Russia the role of the regional press increases. In a competitive environment, very often journalists initiate the appearance of the yellow press or tabloids. At the same time, recent years have seen the reverse process, namely emergence of qualoids. Today's editions are missing a clear separation between journalistic genres; in parallel with this tendency, began to form a new genre forms. Nevertheless, the Tatar-language publications are characterized by thematic narrowness.
\end{abstract}

Keywords: typology of media, media genres, regional journalism, Russian media, Tatar journalism, journalism of the Republic of Tatarstan

\section{Introduction}

In present, the role of the regional press, which largely covers the local life, presenting a certain interest to an audience, rapidly increases. As a result, the local press continues evolving in typological and genre aspects.

Regionalization of the Russian information space is caused both by political, economic, socio-cultural and ideological factors, determining the intensive development of mass media in the country regions (Antonova, 2006, p.28-30). Newly emerging newspapers and magazines cover the topics that due to different political, moral or other backgrounds previously could not appear on the pages of the local press. At the same time, we are witnessing still ongoing process of emergence of new genres and transformation of old ones. Such changes represent a progressive tendency, conjoining their elements: typological characteristics of the publications impose the development of new topics and the application of new genres, where new genres and topics, in turn, change the typological characteristics of publications.

Russian regions retain an interest towards the regional press published in the national languages. The media coverage, social address and the common national ideas of the Tatar-speaking audiences are becoming mainstream in today's world.

\section{Methodologies}

Philosophical and methodological basis of article is formed on the ground of research works that deal with the fundamental problems of scientific knowledge methodology in the field of journalism. This concerns, in particular, the works on the systematization and features of regional mass media, such as the articles of European and American scientists: B. Alysen (Alysen, 2006), E. Castelló (Castelló, 2013), B. Franklin (Franklin, 1998, 2006), D. Heider, M. McCombs, P. M. Poindexter (Heideretal., 2005), B. Jenner (Jenner, 2002), Ph. Kaniss (Kaniss, 1997), M. Mathien (Mathien, 1993), D. O'Neill, C. O’Connor (O'Neilland \& O’Connor, 2008 ), D. Randall (Randall, 2000), P. K. Ravindranath (Ravindranath, 2005), J. Saltzman (Saltzman, 1999), S. Uebbing (Uebbing, 2006).

There are studies by Russian scientists in the theory of journalism, including those, specifically focused on typology and systematization of massmedia (Anikinet.al., 2009; Golovin, 2012; Zassoursky, 2003; Lazutina et.al., 2011; Ovsepian, 1995; Prokhorov, 2011; Tertychny, 2011; Tulupov, 2007; and Shkondin, 2000, 2003). 
The specificity of contemporary functional, typological and genre development of the regional press in the current context becomes the research object as well (Belik \& Lepilkina, 2009; Lebedev, 2009; Mishanin, 2007; Sagitova, 1995).

Given the specificity of the goals and objectives in view, authors followed a systematic approach to the study. "Systematic approach embodies the principles of studying stylistic harmony in the synthesis of structural, functional and genetic concepts of the object" (Kirnoze et al., 2002, p. 35).

Along with the systematic approach, the authors addressed both general scientific (observation and comparative method) and philological (structural method) approaches, as well as particular specific tools including special research techniques, peculiar to philological sciences, such as comparative, problem-chronological, logical, and other procedures. The content analysis method of documents and the typological research method was applied as well.

\section{Results}

In the Republic of Tatarstan there are 742 registered mass media. In terms of press distribution over the territory of the Republic of Tatarstan, there are federal, national, municipal and corporate media. At that, public and non-state-owned (private and corporate) newspapers and magazines go together. Among them 124 papers and 32 magazines are published in the Tatar language, 14 radio and 10 television programs go on air. This is provided by 32 radio and $44 \mathrm{TV}$ channels and 2 news agencies. The Tatar-speaking mass media are functioning not only in the Republic of Tatarstan, but also over the whole Russia and even beyond.

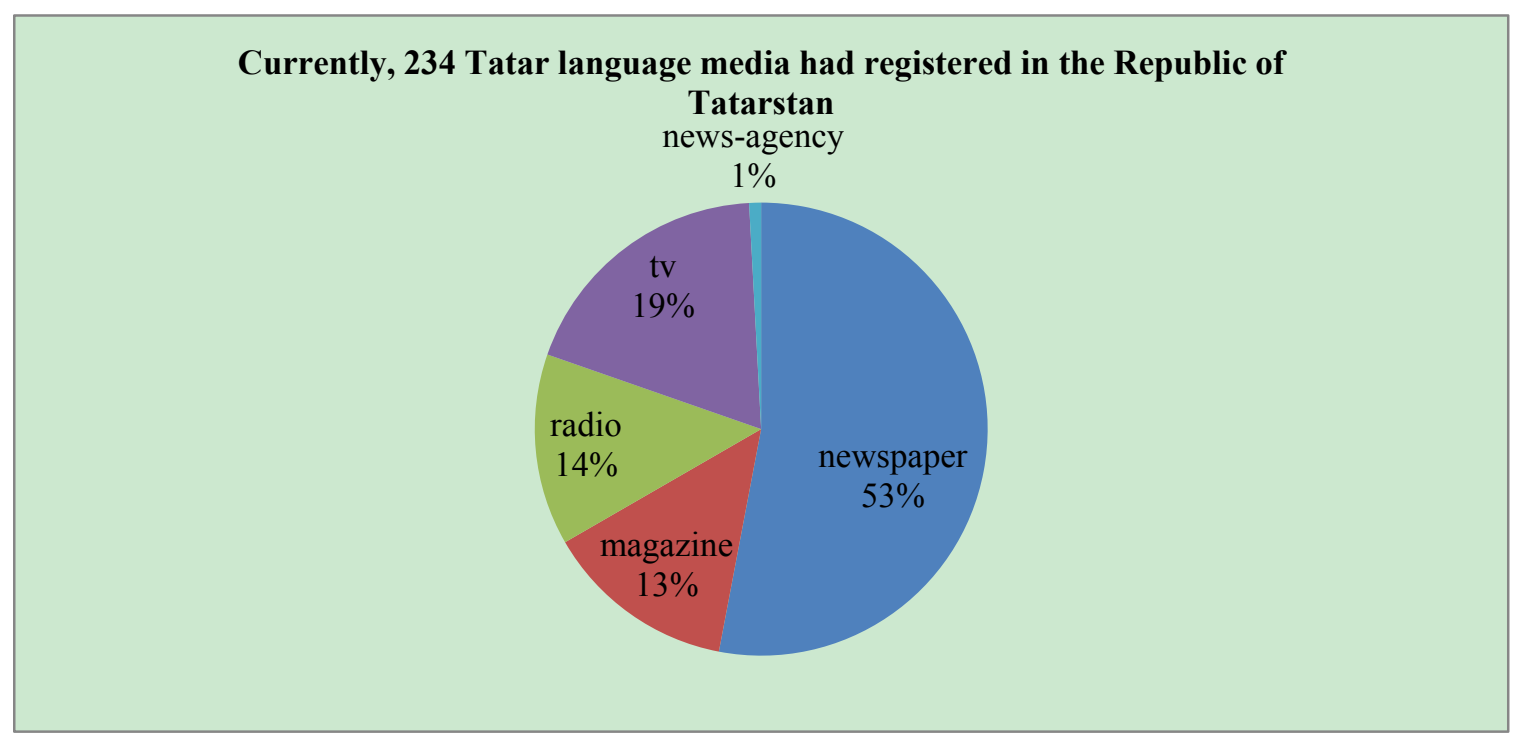

Figure 1.

Since the 90s of the XX century, the Tatar-language printed press in the Republic of Tatarstan began to gradually acquire some signs of tabloids, whereas in the last decade the process was reversed: tabloids were changed to qualoids. The editions are loosing a distinct boundary between the classic journalistic genres; at the same time, the Tatar periodicals have been joined by a number of publications that pretended to their own genre clearness. These are small volume mediatexts. A certain thematic narrowness is noted in the Tatar-language media, which lacks highlights on financial and economic issues, as well as business problems or the legal sphere aspects. In this regard, the regional press in Russia should necessarily further develop and undergo reforming by enhancing journalists' professional competences. Public funding of the most socially significant projects would help to deepen and develop the system of regional publications.

\section{Discussion}

\subsection{The Tatar-Language Massmedia System}

It is important to study the publications typology: this will help to determine the niche of regional media in the Russian mass media. 
The audience usually prefers regional mass media. This is due to the fact that the local editorial policy has the means and opportunity to consider fully the information needs of the local population. (Kaptyuhin \& Romanov, 2013).

According to administrative and territorial distribution level, all newspapers and magazines are divided into federal, regional and local. In terms of the intended purpose, they may be sectorial and specialized, but the most frequently they are versatile. Depending on the publication time they are distinguished as morning and evening editions. In terms of their content, today's printed matter can be either of high quality, general, or "yellow". At the same time, there are other distinguished type-forming peculiarities of newspapers and magazines: these are audience age, gender, preferences and interests. Currently, high quality newspapers acquire certain signs that indicate their transformation into general media. At the same time, general media, on the contrary, seek to get closer to quality editions.

As of July 2014, in the Republic of Tatarstan there are742 registered mass media (newspapers, magazines, radio and television programs, radio- and television channels, news agencies, and others). (These and subsequent data are taken from the Roscomnadzor report "The results of the operation of Federal Supervision Agency for Information Technologies and Communications of the Republic of Tatarstan" (Roscomnadzor, 2014)).

In terms of territorial distribution of the media, in the Republic of Tatarstan there are federal newspapers, distributed over the Russian Federation and CIS: "Georesursy" (Georesourses), "Sam hozyin" (The Owner), "El-kyybla" (Kyybla is a direction towards the Kaaba), "Pravoslavny Bulgar" (Orthodox Bulgar), "Medeni Zhomga" (Cultural Friday), "Beam Radio", and "Tatar Radiosy" (Tatar radio); media, distributed only in Republic, such as "Beznen gezhit" (Our newspaper), "Svesda Povolzhya" (Star of the Volga Region) and "Vechernya Kazan" (Evening Kazan) municipal editions, such as local newspapers "S vami" (With You) and "Chistopolskaya Pravda"; as well as corporate media: "Kurs Rimera-Alnas" (Riemer-Alnas Course), "ALNAS", "Rabocheeslovo" (Labor Word) and "Elecon". The latter may also include the media issued by higher educational institutions, such as for example, "Economist" (The Economist) and "Kazanckyi universitet" (University of Kazan).

In the Republic of Tatarstan are published both state-owned and non-governmental (private and corporate) communication media. Federal networks ("Inter Media Group", "RusMedia" and "STS") are joined by emerging regional media holdings, such as "Tatmedia", "Edinstvo" (Unity), "Juldash" (Satellite) and "Akcharlak" (Seagull) publishing houses. Republican mass media cover all audience niches, ranging from young children to adults of advanced years, who can find the media both in Russian and Tatar languages depending on their interests and preferences. The newspapers, such as "Kuchtenech" (Gift), "Salavat Kupere" (Rainbow), "Sabantuy" (National fest sabantuy), "Kumesh Kyngyrau" (Silver Bell), "Yalkyn" (Flame), "Idel" (Idel - River), "Tatarstan yashlere" (Youth of Tatarstan),"Beznen gezhit" (Our Newspaper),"Akcharlak" (Seagull) and "Yuldash" (Satellite) are of interest to different categories of readers. For example, magazines "Syuyumbike" (Syuyumbike, queen of Kazan Khanate) and "Sterva"(Vixen) are destined for women, where as "First Key" and "Men's City" are meant for men.

On the subject of lighting in RT, there are editions, which are focused on socio-political issues, such as "Vatanym Tatarstan" (My Homeland Tatarstan) and "Svesda Povolzhya" (Star of the Volga Region); spiritual problems: "Islam-Info", "Muselmannar" (Muslims) and "Shivonosnyi istochnik" (Life-giving Spring). Some editions focus on construction issues, such as "Zagorodnyi club" (Country Club) and "Hozyain doma" (Master of the House), as well as housing services and utilities problems: "TCZH Center" (HS\&U Center) and "Nadezhnaya kompaniya" (Reliable Company). Some deal with agriculture: "Agromedia", "Promintel Agro", "Avylym", and "Zemlya-Zemlitsa" (Bit of land); medicine: "Healthy Nation", Kazan Medical Journal" and "Practical Medicine for Everybody"; sports line:"Grani rubina"(Facets of Ruby) and "Hockey PRO", gardening: "Sam hozyain" (Proprietor) and "Organic Farming Club"; and some others. There are about 40 corporate mass media and more than 120 advertising editions, whose circulation ranges between 3 and 300 thousand copies.

The Tatar-language massmedia are distributed not only in the Republic of Tatarstan, but also in Russia and even beyond the Russian Federation. In addition to the above-mentioned publications, 42 newspapers and 27 magazines are distributed in Russia, as well as 4 radio-channels and 7 tele-channels broadcast in Russia. Twelve radio-channels, seven TV-channels and seven news agencies are broad-custing in the Tatar language.

Newspapers "Hezine" (Treasure), "Tatar Ruhy" (Tatar spirit) and "Ak Bars" (which is an insert to the "Chelyabinsk Worker" newspaper) are published in Chelyabinsk region together with operating there "Vatan" (Homeland) radio program. The newspapers "Umet" (Hope), "Kumek Kuch" (Strength is in Unity) are issued in Ulyanovsk region along with "Chishme" (Spring) TV show. Perm region publishes the newspaper "Tan" (Dawn). 
More than ten types of TV and radio programs with duration from 5 to 70 minutes go on the air in this region. A well-developed network of the Tatar media is in Udmurtia: newspapers are published both in Izhevsk and Mozhga town. Newspaper "Yanarysh" (Renaissance) is known outside Udmurtia and can be subscribed in Tatarstan as well. Besides the newspaper, there are several TV and radio programs, produced by the State TV and Radio Broadcasting Company (STRBC) "Udmurtia", as well as TV and Radio Company "My Udmurtia", and intended for the Tatars living in the country; these are "Heerle Kitsch" (Good Evening), "Kumesh Kyngyrau" (Silver Bell), "Heerle irte" (Good Morning), "Beznen vakyt" (Our Times) and others. Samara region issues the newspapers "Berdemlek" (Unity), "Qamishli Heberlere" (Qamishli-village News), airs radio programs "Idelkeem" (My Volga) and "Ak Behet" (Good luck).

It may be noted that the newspaper "Azan" (Call to prayer), which is published in Russian, is intended to the Russian-speaking Tatars. There are a lot of similar examples all over Russia: in St. Petersburg there is a newspaper "Nur" (Ray) for Russian Tatars, in the Penza Region -the newspaper "Penza Majlis", in the Sverdlovsk Region - "Istina"(The Truth), in the Krasnoyarsk Region - "Nur" (Ray). The newsletter "Tatarlar" (Tatars, living in Khanty Mansiysk Autonomous Region "Ugra"), the newspapers "Azat Seber" (Free Siberia, Novosibirsk Region), "Idel" (Astrakhan Region), "Tatar Dunyasy" (Tatar world, Omsk Region) and some others are bilingual.

These examples testify that the interest in the local press, published in the national languages, increases not only in Tatarstan, but also in other regions, because exactly these media can be most sensitive to cultural and national traditions of the audience.

It should also be noted that newspapers and magazines were published in the Tatar language outside of Russia and the former Soviet Union since the beginning of the XX century. For example, it is known that 66 newspapers and magazines were published outside of Russia. Most of them were issued in Germany, China, Turkey, Finland and Japan. In addition, the Tatar emigre press was distributed in Romania, Hungary, Sweden and the United States (Garifullin \& Sabirova, 2014). According to information of "Tatar Ile" portal, currently in the CIS and western countries there are 18 various Tatar mass media: newspapers, electronic periodicals and radio programs. They are available in Kazakhstan: "Ak Bars" (White Panther) and "Semipalat tatarlary" (Tartars of Semipalatinsk); Kyrgyzstan "Tugan Tel" (Native Language); Belarus: "Svet Islama"(Light of Islam); Latvia: "Chishme" (Spring); Poland: "Przeglad Tatarski" (Tatar View); Romania; "Kara Deniz"; and Turkey: "Terkiya avazy" (Voice of Turkey), radio broad casting (Tatar ile, 2014).

The mass media in the Tatar language, as well as all other media, existing in the world, are combined into typological groups depending on the factors that are used in the typological analysis. Particularly, it should be noted that media coverage, social address and common national ideas of Tatar-language audience are becoming mainstream in the today's world.

In the typological structure of the contemporary Tatar-language media, which are published outside the Republic of Tatarstan and Russia, a special place belongs to the newspapers that may account for their active ability and importance in maintaining an integrated Tatar ethnie.

At the same time press in the Republic of Tatarstan is more qualified owing to other typological factors, since the representatives of audience committed to these editions are rarely united by common idea of an integrated Tatar nation, since the social problems are at the forefront.

Tatars from other countries (including those who live in the United States and Canada) are able to read the latest press in their native language and watch TV via the Internet. For example, the TV channel "Tatarstan-New Century» (www.tnv.ru) is the only channel in Volga region with the largest coverage in the signal in satellite, analog and digital terrestrial broadcast. At the same site there is a broadcasting channel "TNV-Planet" and radio stations. There are radio stations that broadcast via the Internet - Qazan Radiosi (www.qazan-radiosi.com), Azan radiosy (http://radioazan.ru), Azatlyk radiosy (http://www.azatliq.org). Distribution of printed materials outside Russia there is without organization subscription, but on its own editorial board and on the initiative of the Tatar community. At the same time the content of newspapers and magazines are available in the Internet, for example, websites www.vatantat.ru, www.shahrikazan.com, www.beznen.ru, www.syuyumbike.ru, www.kazanutlary.ru and etc.

\subsection{Typological Changes in Tatar-Language Periodicals}

Typology of Tatar-language press was also affected by economic difficulties. "The crisis has not stopped the transformation process of newspaper and magazine printing industry in Russia into an effective business that began in the turn of century, though slowed it down significantly" (Vedeneyeva, 2010). 
It is known that the press cannot exist only at the expense of national ideas. After all, in a market economy printed matter becomes a commodity. To improve the circulation, journalists initiate tabloidization of theregional press. This process began in Russia as early as in the 90s of the XX century. The main feature of tabloid, printed in A3 format, is that it is based on infotainment (derivative from the entertainment), i.e. the desire to entertain through the information.

There is widespread belief that "these editions have a decisive influence on the outlook and attitude of the Russian public; they create a new style of press consumption. Quality newspaper publishers cannot ignore this tendency" (Kirshin, 2009, p. 43).

These publications lack analytics, materials, small in terms of volume, are presented in a way that does not give nourishment to the human mind; the main focus is given to bright, large photographs, effecting on the emotional side of human nature. Unfortunately, at the moment, infoteyment appears even in the quite serious newspapers. Not so much the advertisers, journalists and editors, but the readers positively relate to this fact; moreover, they require this: a serious information is often presented in the form of easy reading material for better readability.

At the same time, in recent years, we observe the reverse process, namely appearance of qualoids. Qualoidis a derivative fromquails and tabloid, and means quality tabloid. It is kind of possible balance between quality and tabloid press. In Tatar-language press a variety of publications meet the requirements of qualoids, which contain both the analytical materials on the economic state of the Republic of Tatarstan and shoddy anecdotes and light reading about the afterlife. In terms of their layout, these publications are very similar to tabloids; they have the same format, large pictures, their language and demotic style are more popular than literary style. Though at the same time, their innovative original layout and creative thinking are worthy of interest. The pages of such publications contain articles that consider deep social problems of our reality and various spheres of human activity. Qualoid, as a special type of mass newspaper, is not specified in terms of its content, it includes everything, becomes a universal edition and seeks to get closer to its audience by organizing meetings, "round table discussions", playing the lottery, handing out questionnaires and willingly accepting phone calls to the editorial office.

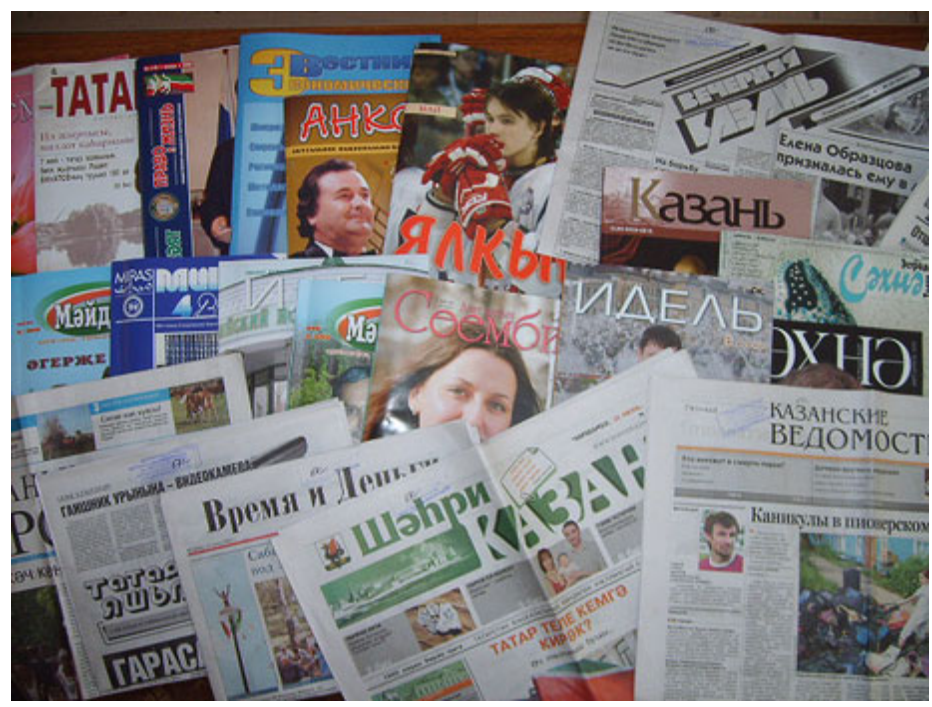

Figure 2 .

\subsection{Genre Features of Regional Tatar-Language Editions}

Today's editions have lost a clear separation between journalistic genres. In all fairness it should be noted that a strict separation of genres in contemporary journalism anyway exists only in theory, because the genres interpenetrate to each other, passing a certain evolution in the process of their development. It is this evolution that allows genres constantly expand due to updating of the "genre palette". This is evidenced by the observation of the written content of Tatar periodicals. For example, the notice in the daily newspaper is very often accompanied by additional forms of information personalization ("quote of the day" and "direct speech"). At the same time there are hybrid forms, similar to the "quiz" interview (in normal interview journalist gets answers to his questions from one person, while in the quiz he gets answers on the same question from many people). In 
addition, we see new sustainable types of analytical publications, such as sociological summary, monitoring, rating, analytical press release and others.

Unfortunately, today's journalists are often ignoring traditional canons, whereby genres are deprived of their own sounding and become more amorphous, and sometimes impersonal. This leads to the loss of the expected rational and emotional impact on the audience.

At the same time, in Tatar periodicals appended in a number of publications that claim to own genre definition. It is usually small mediatexts, placed under the headings of "Advice", "Hotline" and "Classifieds". For example, the newspaper "Vatanym Tatarstan" publishes very popular topic "Bulmas, dimə" ("It cannot be true") and "Gamle engeme" ("Important conversation"); in the "Akcharlak" newspaper there is a classified column "Bez eitmedek" ("This is said not by us"), as well as "Fiker" ("Opinion") in the "Tatarstan yashlere" newspaper.

Any edition must take into account business environment of newspaper market, bringing its product in accordance with market demands. "However, the most important element of this strategy is the constant adaptation of the product to the needs of readers. Daily regional newspapers, as well as all other publications, modify their information presentation forms, first of all, in the light of the audience habits and tests. Style of the materials, published in daily regional newspapers, as well as in all other publication media, is utterly laconic. Journalists tend to present a maximum of facts, using a minimum of phrases: at the modern pace of life, very few people have time to read through the entire newspaper every day from beginning to end" (Solomonov, 2003, p.69).

There is a certain thematic narrowness of Tatar-language publications (most of the publications are focused on the official chronicle, agricultural issues, family problems, relationships in the community, as well as the national culture and language, education and religion), while the Russian-language press in the Republic of Tatarstan extensively highlights the financial, economic and business issues, as well as the legal sphere. In our opinion, the reason for narrowness of information discourse can be explained by the fact that the edition is focused on the narrow Tatar-speaking audience, mostly villagers or first generation citizens, who are more concerned about their own social problems, rather than issues related to the development of society in financial and economic terms. "Distortion of objective and topical medium in mass media content, as well as inability to reproduce many of its fragments, adversely affect the formation of the spiritual potential of the society, inclusion of the various population strata to intellectual potential" (Anikin et al., 2009, p. 28).

Certainly, it is necessary to further develop and reform the regional press in Russia. "This problem has been and still remains particularly topical because over $60 \%$ of the citizens in the Russian Federation live in settlements with a population below 250 thousand people" (Ivanov, 2012, p. 229).

Reform should be taken seriously both by publishers and government agencies. Publishers and journalists need to start paying more attention to the needs of the target audience. Professional development of national journalists, including those writing in Tatar language "is, in the truest sense of the word, a national problem, much more important than private commercial interests of the certain administrator". So says P.Gutiontov, Secretary of the Union of Russian Journalists and the Chairman of the Committee on Protection of Speech Freedom and the Rights of Journalists. We must "raise the level of journalists' self-esteem, not putting it off till tomorrow, and on this basis to raise the level of respect for them. We have to seek adoption of laws that would make possible the actual independence of the local press, to seek understanding the fact that the journalist performs the most important social function, and in this sense he is irreplaceable and thus must be protected" (Gutiontov, 2011).

Public funding of the most socially significant projects would help to deepen and develop the system of regional publications. We should also pay attention to the opportunities of publishing free newspapers. At the time, when the market of free newspapers in Russian language is saturated, investors do not particularly pay attention to free editions in Tatar language: apparently, in the regional domestic markets there is no money for such projects.

\section{Conclusion}

Historical and cultural traditions of the population actively influence the development of regional mass media. The local press is able to be more flexible with due consideration of all the peculiarities of local audience (Voronin, 2001, p. 19).

Today local newspapers and magazines have become real competitors toward metropolitan publications, because their information and advertising is much closer to the needs and interests of local audiences.

Unfortunately, in a competitive environment, very often journalists initiate the appearance of the yellow press. At the same time, recent years have seen the reverse process, namely emergence of qualoids. Publications are 
missing a clear separation between journalistic genres. At the same time, new genre forms began to emerge in Tatar-language publications. Authors note thematic narrowness of Tatar-language editions, which very rarely and cursorily cover a range of issues concerning society evolution problems. In this connection, it should be noted that the regional press of Russia should continue to advance and undergo reforming. This requires public financing of the most socially significant projects. It is advisable to carry out sociological and marketing research in order to identify the right kinds and types of publications, their topics, as well as topics of existing editions. Important is to find out the most effective forms for submitting print media in the Tatar language towards contributing to the progress of social consciousness and the development of the Tatar community.

\section{References}

Alysen, B. (2006). The Electronic Reporter: Broadcast Journalism in Australia. Sidney: UNSW Press.

Anikina, M. E., Baranov, V. V., \& Voronov, O. A. (2009). Typology of the periodical press. M.: Aspect Press.

Antonova, V. I. (2006). Transformation of typological and genre systems in contemporary journalism (based on printed publications in the Volga Region). Ph.D. thesis, Mordovian State University, Saransk.

Castelló, E. (2013). Framing news on risk industries: Local journalism and conditioning factors. Journalism, 11(4), 463-480. http://dx.doi.org/10.1177/1464884910367592

Franklin, B. (2006). Local Journalism and Local Media: Making the Local News. New York: Routledge.

Franklin, B., \& Murphy, D. (1998). Making the Local News: Local Journalism in Context. Hove: Psychology Press.

Garifullin, V. Z., \& Sabirova, L. R. (2014). Place of Internet resources in the system of Islamic mass media in Russia. World Applied Sciences Journal, 30(12), 1808-1810.

Golovin, Yu. A. (2012). Magazine periodicals: typological characteristics. Problems on the journalism theory and practice, 2, 72-82.

Gutiontov, P. Prospects of the regional mass media development in Russia. Retrieved from http://www.ruj.ru/_ruk_articles/pavel_gutiontov/perspektivy_razvitiya_regionalnykh_smi_v_rossii/.

Heider, D., McCombs, M., \& Poindexter, P. M. (2005). What the public expects of local news: Views on public and traditional journalism. Journalism \& Mass Communication Quarterly, 82(4), 952-967. http://dx.doi.org/10.1177/107769900508200412

Ivanov, V. K. (2012). Features of contemporary Russian regional press. Young scientist, 10, 228-230.

Jenner, B. (2002). Local journalism on the WEB. British Journalism Review, 13(1), 32-35. http://dx.doi.org/10.1177/095647480201300105

Kaniss, P. (1997). Making local news. Chicago: University of Chicago Press.

Kaptyuhin, R. V., \& Romanov, A. A. (2014). Prospects for the development of electronic mass media. Proceedings of the XXXIII scientific-practical conference "Economy and modern management: tHEORY and practice", 1(33). Novosibirsk.

Kirnoze, Z. I., Zinchenko V. G., \& Zusman, V. G. (2002). Methods of studying literature. A systematic approach. M.: Flint: Science.

Kirshin, B. N. (2009). Regional press: current trends in the national media market. Herald of the Chelyabinsk State University, 17(155), 42-45.

Lazutina, G. V., \& Raspopova, S. S. (2011). Journalistic creativity genres. Textbook for university students. M.: Aspect Press.

Lebedev, A. A. (2004). The post-Soviet mass media in the Republic of Tatarstan: Attempt of periodization. Proceedings of the scientific-practical conference "Journalism in 2003: Attainments gaining and losses, development strategy. Moscow State University.

Mathien, M. (1993). Regional dailies (3rd ed.). Paris: PUF.

O'Neill, D., \& O'Connor, C. (2008). The passive journalist: How sources dominate local news. Journalism Practice, 2(3), 487-500. http://dx.doi.org/10.1080/17512780802281248

Ovsepian, R. P. (1995). Russian periodicals: system and typology. M.: Moscow Extern Humanitarian University.

Progress reports of the Federal Supervision Agency for Information Technologies and Communications (Roscomnadzor). Retrieved from http://www.16.rkn.gov.ru/plans-and-reports/reports 
Prokhorov, E. P. (2011). Introduction to the theory of journalism. Text book for students (8th ed.). M.: Aspect Press.

Randall, D. (2000). The universal journalist. London: Pluto Press.

Ravindranath, P. K. (2005). Indian Regional Journalism. New Delhi: Authorspress.

Regional journalism in terms of socio-economic transformation in the XIX-XXI centuries. (2009). Proceedings of the international scientific-practical conference, Stavropol.

Regional journalism in the Russian mass media: Dynamics and development features in a new environment. (2006). Proceedings of all-Russia scientific-practical conference, dedicated to $100^{\text {th }}$ anniversary of journalism in Mordovia, Saransk.

Sagitova, L. V. (1995). The national press as a factor in the national identity formation in Tatarstan in the current context. Sovereignty and ethnic identity: the ideology and practice. M.

Saltzman, J. (1999). Local TV-news: Journalism on the run. USA Today Magazine, 127(2648), 53.

Shkondin, M. V. (2000). Transformation of the typological structure of Russian media: Systemic aspects. From books to the Internet: journalism and literature at the dawn of the new millennium: A collection of articles. M.: MSU Publisher.

Shkondin, M. V. (2003). Newspaper and magazine typology in the context of the formation of the communicative system of the information society. Bulletin of the Moscow University, 10, Journalism(2), 12-32.

Solomonov, Yu. (2003). Regional press in France. History and secrets of daily newspapers success (p. 135). M.: RIP-holding.

Tatarile. Tatar mass media in the foreign countries. Retrieved from http://www.tatarile.org/congress/ru/content/ татарские-средства-массовой-информации-в-странах-зарубежья.

Tertychny, A. A. (2011). Genres of the Periodical Press: Textbook for students (p. 320). M.: Aspect Press.

Tulupov, V. V. Theoretical and practical aspects of the printed periodicals typology. RELGA: electronic scientific-cultural magazine. Retrieved from http:/www.relga.ru/Environ/WebObjects/tgu-www.woa/wa/ Main?textid=1970\&level1 $=$ main\&level2 $=$ articles

Uebbing, S. (2006). Tri-medial working in European local journalism, Sandra Uebbing. Bonn: Reinhard Fischer.

Vedeneyeva, N. V. (2010). Problems and prospects of printed media development. Analytical Bulletin of the RF Federation Council, 16. Retrieved from http://www.budgetrf.ru/Publications/Magazines/VestnikSF/2010/ VSF_NEW201008051902/VSF_NEW201008051902_p_005.htm

Voronina, N. I. (2001). Theoretical cultural research. Saransk: Mordovia University Publisher.

Zasursky, Y. N. (2003). Mass media system in Russia: A textbook for high schools. M.: Aspect Press.

\section{Copyrights}

Copyright for this article is retained by the author(s), with first publication rights granted to the journal.

This is an open-access article distributed under the terms and conditions of the Creative Commons Attribution license (http://creativecommons.org/licenses/by/3.0/). 